\title{
Production and resource partitioning in the giant scallop Placopecten magellanicus grown on the bottom and in suspended culture
}

\author{
B. A. MacDonald* \\ Marine Sciences Research Laboratory, Memorial University of Newfoundland, St. John's, Newfoundland A1C 5S7, Canada
}

\begin{abstract}
Growth rates of shell and somatic tissue plus quantities of energy invested in the production of gametes, soma, and shell were determined for cultured Placopecten magellanicus and compared to similar estimates for a natural population in Newfoundland. Cultivated scallops $<7$ yr old displayed faster shell growth, heavier somatic weights, greater annual reproductive output and total production than wild scallops of equivalent age but placed less emphasis on shell production and had lower turnover ratios $(\mathrm{P} / \mathrm{B})$. In response to enhanced conditions associated with suspended culture these scallops allocated more of their available energy to somatic growth and there were also indications that maximum size and longevity were reduced. The potential consequences of less emphasis on reproduction, reduced maximum size, and longevity include an overall reduction in gamete production throughout the lifespan and an apparent decline in fitness.
\end{abstract}

\section{INTRODUCTION}

The influence of environmental temperature and food availability on bivalve growth and reproduction has provided a focal point for a substantial number of recent studies (for review see Bayne \& Newell 1983). Such investigations often require production measurements in order to evaluate commercially important species and their potential productivity in different habitats, which is especially relevant for mariculture operations. The approach often adopted has been to monitor growth and occasionally reproductive activity along a gradient of measured or assumed environmental change. Interpretation of the data, however, is often complicated by spatial, temporal, and natural variability, which is often not taken into consideration when estimating production (Griffiths 1981, Broom 1983). Whereas some of the more obvious effects of various environmental factors on bivalve growth and reproduction have been determined, subtle effects on resource allocation patterns and the ensuing consequences to individuals and populations have received little attention and are not well understood.

\footnotetext{
- Present address: Division of Sciences, University of New Brunswick, PO Box 5050, Saint John, New Brunswick E2L 4L5, Canada

The physiological ecology of Placopecten magellanicus and the influence of temperature and food availability on growth and reproductive characteristics of several populations has been described by MacDonald \& Thompson (1985a, b, 1986) and MacDonald et al. (unpubl.). These studies demonstrated slower rates of growth, less reproductive output, reduced rates of gamete development and proportionately less available energy allocated to reproduction in scallops from deep water than in those from shallow water as a result of less favorable environmental conditions in greater depths. Determining if scallop cultivation is better suited to conditions associated with suspended or bottom culture, and whether a physiological basis exists for observed differences between these groups of scallops, may be achieved by monitoring their growth and reproductive output, because they are good indicators of environmental suitability and represent the integrated response of all processes of physiological energetics in the organism. In this paper, age-specific somatic growth, shell production, reproductive output and energy partitioning patterns were determined for cultured $P$. magellanicus for comparison with a population of the same species grown under more natural conditions in a scallop bed. The objective of this study was to gain insight into how scallops would respond, in terms of partitioning energy between growth and 
reproduction, to artificially enhanced conditions associated with suspended culture and the potential consequences attributable to any observed changes.

\section{MATERIALS AND METHODS}

Scallops that had grown at a water depth of 10 to $15 \mathrm{~m}$ under conditions of a 3-phase suspension operation in Spencers Cove $\left(46^{\circ} 39^{\prime} \mathrm{N}, 54^{\circ} 05^{\prime} \mathrm{W}\right)$ were provided by the Department of Fisheries and Oceans in St John's during 1981, 1982, and 1983. Juveniles were initially acquired from monofilament line in suspended spat collectors before being transferred to pearl nets for the intermediate stages and to lantern nets for the final growout phase (Ventilla 1982). Scallops growing under natural conditions on the bottom were collected from a depth of 10 to $15 \mathrm{~m}$ in nearby Southern Harbour $\left(46^{\circ} 35^{\prime} \mathrm{N}, 53^{\circ} 36^{\prime} \mathrm{W}\right)$ by SCUBA divers during 1983. A size range of scallops was sampled from each of the 2 sites before (August) and after their single period of spawning (October/ November) in order to estimate gonad weight loss on spawning and to determine size- and age-specific gamete output (MacDonald \& Thompson 1985b).

Ages of individual scallops from Southern Harbour were estimated by interpreting external growth rings on the shell (Stevenson \& Dickie 1954) and growth increments on the calcareous portion of the ligament (Merrill et al. 1966). Both of these methods described useful age markers for Placopecten magellanicus. Gonads of individual scallops were separated from the remaining body tissue (somatic) and weights recorded separately after drying at $90^{\circ} \mathrm{C}$ for $48 \mathrm{~h}$. Total shell weight was also recorded and shell height [maximum distance between dorsal (hinge) and ventral margins (Seed 1980)] measured to the nearest $0.1 \mathrm{~mm}$ using vernier calipers.

The Von Bertalanffy function was fitted to the data and used to predict mean shell heights for each age class with the following equation:

$$
H_{t}=H_{\infty}\left[1-e^{-k\left(t-t_{0}\right)}\right]
$$

where $\mathrm{H}_{\mathrm{t}}=$ shell height at time $\mathrm{t} ; \mathrm{H}_{\infty}=$ mean asymptotic shell height; $\mathrm{k}=$ the Brody growth coefficient; and $t_{0}=a$ parameter representing time when shell height equals zero. Mean somatic weight for each age class was predicted from a polynomial regression equation fitted to the data, which has some advantages over the Von Bertalanffy function for describing somatic growth rates (MacDonald \& Thompson 1985a). Polynomial regression is described by the following equation:

$$
y=\beta_{0}+\beta_{1} x+\beta_{2} x^{2}+\beta_{3} x^{3} \ldots \beta_{m} x^{m}+\varepsilon
$$

where $\beta_{0}, \beta_{1} \ldots \beta_{\mathrm{m}}$ are population parameters; $y=$ the predicted somatic weight for a given value of $x$ (age); and $\varepsilon$ is random error at observation $x\left[N . B . \beta_{0}=\alpha\right.$ in Zar's (1984) notation]. Multicollinearity in this type of regression can be reduced by replacing values of $x$ with $(\mathrm{x}-\overline{\mathrm{x}})$ (Neter et al. 1983).

For predictive and comparative purposes relations between shell height and other variables (soma, gonad, and shell weight) were fitted to the allometric equation $\mathrm{y}=\mathrm{ax}{ }^{\mathrm{b}}$, where $\mathrm{y}=$ predicted weight at a given shell height and $\mathrm{a}$ and $\mathrm{b}=$ fitted parameters. $\mathrm{A}$ linear form of this equation may be obtained by transforming both variates to logarithms and fitting the data by least squares regression to a straight line (Snedecor \& Cochran 1972). Non-linear procedures (NLIN) in the Statistical Analysis System (SAS Institute Inc.) were used to construct Von Bertalanffy models and General Linear Model (GLM) procedures were used to calculate and compare regressions.

Total production $(\mathrm{P})$ in bivalves may be partitioned among several components:

$$
P=P_{g}+P_{r}+P_{s}+P_{b y}
$$

where $\mathrm{P}_{\mathrm{g}}=$ energy invested in somatic tissue growth; $\mathrm{P}_{\mathrm{r}}=$ energy expended on gametes; and $\mathrm{P}_{\mathrm{s}}=$ energy incorporated in the organic matrix of the shell. According to Caddy (1972) byssus threads are not routinely observed in Placopecten magellanicus especially in older individuals, so byssus production $\left(\mathrm{P}_{\text {by }}\right)$ was not estimated in this study, although in other bivalves such as Chlamys spp. (Vahl 1981, Shafee \& Conan 1984) and Mytilus edulis (Hawkins \& Bayne 1985) synthesis of byssal threads may require a significant amount of energy. Because there were no consistent differences in somatic or gonad weight relations between male and female scallops, samples of both sexes were combined to estimate production.

Gamete production $\left(P_{r}\right)$ was estimated for each age class using mean shell heights to calculate gonad weight loss on spawning from logarithmic regressions for pre- and post-spawning scallops, where $1 \mathrm{~g}$ dry weight of gametes $=26.0 \mathrm{~kJ}$ (MacDonald \& Thompson $1985 b)$. Somatic tissue production $\left(P_{g}\right)$ was calculated from increments in somatic weight between consecutive year classes $\left[W_{(t+1)}-W_{t}\right]$ obtained from polynomial equations, where $\mathrm{t}=$ age in $\mathrm{yr}$ and $1 \mathrm{~g}$ dry weight of soma $=24.5 \mathrm{~kJ}$ (Thompson 1977). Annual increments in shell weight were calculated for each age class using mean shell heights and logarithmic regressions. These increments were then multiplied by the organic content of the shell $(1.3 \%)$ to estimate shell production $\left(\mathrm{P}_{\mathrm{s}}\right)$, where $1 \mathrm{~g}$ organic matter in shell = $21.1 \mathrm{~kJ}$ (Hughes 1970).

Reproductive effort (RE), defined by Browne \& Russell-Hunter (1978) as the proportion of non-respired 
assimilation or production dedicated to reproduction, was calculated as $R E=\left(\mathrm{P}_{\mathrm{r}} / \mathrm{P}\right) \times 100$ for each age class . Since observed differences in age-specific RE between populations may be related to different rates of growth, a method using growth coefficients $(\mathrm{k})$ and asymptotic sizes $\left(\mathrm{L}_{\infty}\right)$ to transform the independent variable (age) and reduce growth rate effects has been used by Hughes \& Roberts (1980) and Bayne et al. (1983). However, an alternative procedure was used in this study to compare RE for scallops of standard somatic weight regardless of their age, growth rate or asymptotic size. A series of standard somatic weights (in increments of $2.5 \mathrm{gl}$ was selected and the corresponding shell height for each weight class predicted from growth curves. These predicted heights were then used to estimate $\mathrm{P}_{\mathrm{r}}$ for each weight class by calculating weight loss of the gonad on spawning with regressions of gonad weight and shell height.

\section{RESULTS}

\section{Comparisons of growth and production}

Scallops grown in Spencers Cove under conditions of suspended culture had greater shell heights and somatic weights at a given age $(<8 \mathrm{yr})$ than scallops that had grown on the bottom in nearby Southern Harbour (Fig. 1a, b). Von Bertalanffy parameters indi- cated that cultivated scallops achieved their smaller asymptotic size at a faster rate than naturally grown scallops (Table 1).

Annual somatic production $\left(\mathrm{P}_{\mathrm{g}}\right)$ reached a peak at age $3 \mathrm{yr}$ in cultured scallops before steadily declining, in contrast to a later more protracted peak between 4 and $6 \mathrm{yr}$ for $\mathrm{P}_{\mathrm{g}}$ in wild scallops, decreasing to near zero by age 19 yr (Fig. 1c). Higher values for $\mathrm{P}_{\mathrm{g}}$ were observed in cultivated specimens than in wild scallops of similar age, except for those greater than $7 \mathrm{yr}$ of age when growth was faster under natural conditions. During the first 5 yr of life cultured scallops increased more rapidly in shell height, which was reflected in greater shell production $\left(\mathrm{P}_{\mathrm{s}}\right)$, whereas in older age classes it was the wild scallops which incorporated more energy into the shell (Table 2). Reproductive output $\left(\mathrm{P}_{\mathrm{r}}\right)$ and total production $(\mathrm{P})$ increased throughout the lifespan for both populations but were always greater in cultured scallops, except at age $8 \mathrm{yr}$ when $P$ was greater for wild scallops due to higher $P_{g}$ and $P_{s}$ values. Turnover ratios $(\mathrm{P} / \mathrm{B})$ declined steadily with age and became independent of age in wild scallops more than 8 yr old, indicating that production (primarily attributable to $\mathrm{P}_{\mathrm{r}}$ ) increased with somatic body weight. Despite the greater reproductive output of cultured scallops $\mathrm{P} / \mathrm{B}$ ratios were generally greater in those grown on the bottom, owing to the significantly smaller body sizes of the latter.
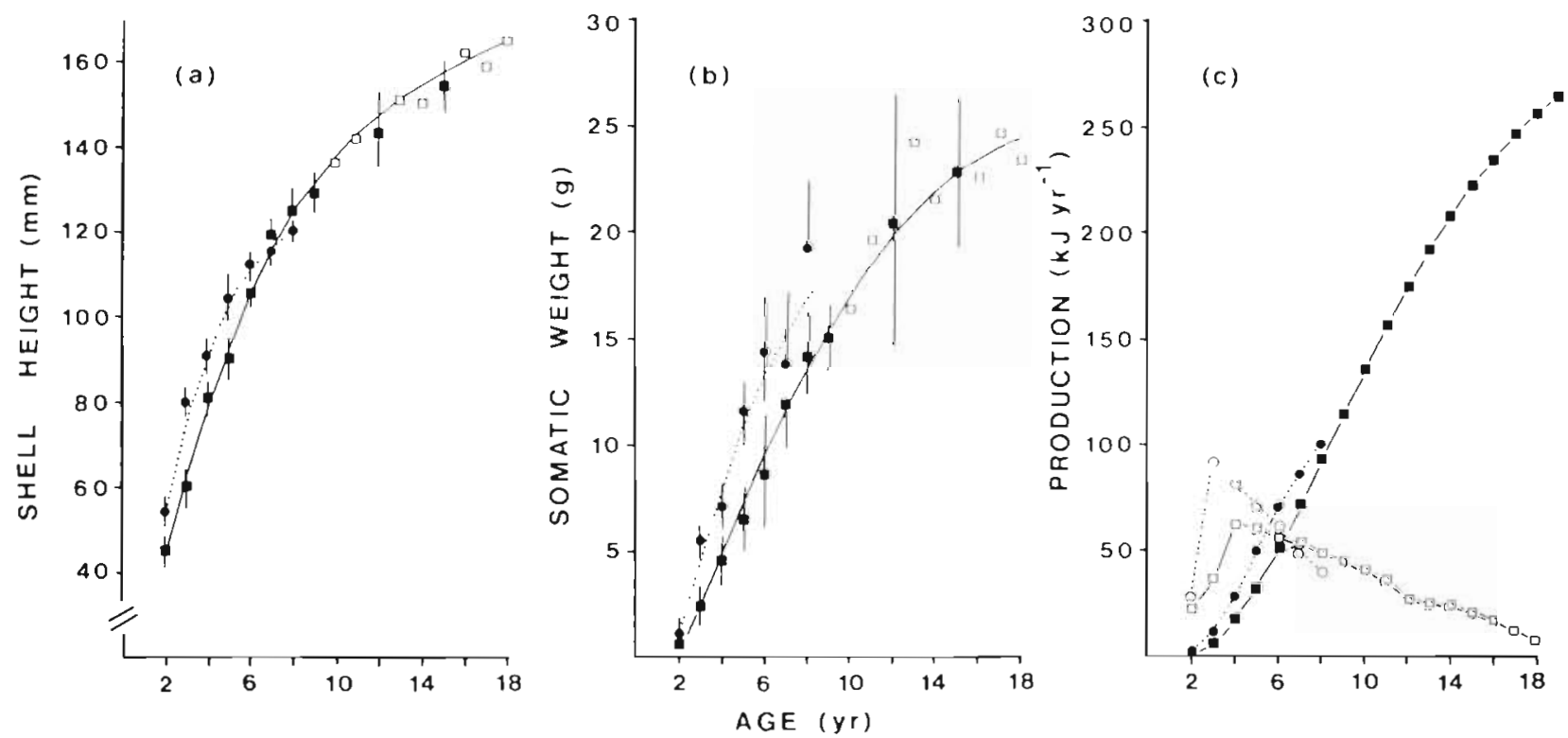

Fig. 1. Placopecten magellanicus. (a) Age-specific shell heights fitted to Von Bertalanffy equations given in Table 1 for cultured (-....) and wild scallops (- - ); (b) age-specific somatic weights fitted to polynomial equations given in Table 1 for cultured $(\bullet \cdots \bullet)$ and wild scallops $(-)$. When $x$ was replaced by $(x-\bar{x})$ in the equations to reduce multicollinearity, a value of 4.82 was used for $\overline{\mathrm{x}}$ in both equations. In (a) and (b) solid symbols and vertical lines represent mean values and their $95 \%$ confidence intervals for age classes consisting of more than 3 individuals; open symbols represent means based on less than 3 samples. (c) Production for each class of cultured $\left[(0 \cdots\right.$.$) ) soma P_{g} ;(\bullet \cdots \bullet)$ gamete $\left.P_{r}\right]$ and wild scallops $\left[(\square-\square)\right.$ soma $P_{g} ;(\square-\square)$ gamete $\left.P_{r}\right]$ 
Table 1. Placopecten magellanicus. Summary of parameters for shell height ( $\mathrm{mm}$ ) and somatic weight data ( $\mathrm{g}$ ) presented in Fig. $1 \mathrm{a}$, b fitted to Von Bertalanffy $H_{t}=H_{\infty}\left[1-e^{-k\left(t-t_{0}\right)}\right]$ and polynomial regression equations $y=\beta_{o}+\beta_{1} x+\beta_{2} x^{2}$, respectively for all age classes sampled in the cultured ( 2 to $8 \mathrm{yr}$ ) and wild populations ( 2 to $19 \mathrm{yr}$ ). See 'Materials and Methods' for details of parameter definitions. Also included are parameters describing the relations between weight (soma, gonad, and shell) and shell height using the allometric equation $\log y=\log a+b \log x$. All equations are highly significant $(p<<0.01)$. Note, pooled data $(1981,1982,1983)$ for cultured scallops were used to ensure the best possible fit to Von Bertalanffy and polynomial equations, however, only 1981 data were combined with 1983 gonad weight data because values for 1982 were much greater than the similar estimates obtained for 1981 and 1983

\begin{tabular}{|c|c|c|c|c|c|c|c|c|c|c|}
\hline & \multicolumn{5}{|c|}{ Cultured } & \multicolumn{5}{|c|}{ Wild } \\
\hline & $\mathrm{H}_{\infty}$ & $\mathrm{k}$ & $t_{0}$ & $\mathrm{n}$ & $r^{2}$ & $\mathrm{H}_{\infty}$ & $\mathrm{k}$ & $t_{0}$ & $\mathrm{n}$ & $r^{2}$ \\
\hline \multirow{2}{*}{$\begin{array}{l}\text { Shell height vs age } \\
\text { (Von Bertalanffy) }\end{array}$} & 127.6 & 0.38 & 0.62 & 200 & 0.91 & 173.8 & 0.16 & 0.22 & 84 & 0.97 \\
\hline & $\beta_{0}$ & $\beta_{1}$ & $\beta_{2}$ & $\mathrm{n}$ & $x^{2}$ & $\beta_{0}$ & $\beta_{1}$ & $\beta_{2}$ & $\mathrm{n}$ & $r^{2}$ \\
\hline \multirow{2}{*}{$\begin{array}{l}\text { Somatic weight vs age } \\
\text { (polynomial) }\end{array}$} & 10.48 & 2.72 & -0.21 & 200 & 0.75 & 6.89 & 2.38 & -0.08 & 84 & 0.95 \\
\hline & & $\log a$ & $\mathrm{~b}$ & $\mathrm{n}$ & $r^{2}$ & \multicolumn{2}{|c|}{$\log a$} & $b$ & $\mathrm{n}$ & $r^{2}$ \\
\hline Somatic weight $v s$ height & & -4.97 & 2.97 & 40 & 0.98 & \multicolumn{2}{|c|}{-4.10} & 2.50 & 84 & 0.97 \\
\hline $\begin{array}{l}\text { Gonad weight vs height } \\
\text { (prespawning condition) }\end{array}$ & & -9.04 & 4.64 & 64 & 0.88 & \multicolumn{2}{|c|}{-6.86} & 3.58 & 40 & 0.77 \\
\hline $\begin{array}{l}\text { Gonad weight vs height } \\
\text { (postspawning condition) }\end{array}$ & & -8.24 & 3.86 & 64 & 0.95 & \multicolumn{2}{|c|}{-7.22} & 3.38 & 44 & 0.95 \\
\hline Shel weight vs height & & -4.29 & 3.06 & 200 & 0.98 & \multicolumn{2}{|c|}{-3.80} & 2.89 & 84 & 0.99 \\
\hline
\end{tabular}

In addition to age-specific production estimates, comparisons were also made of logarithmic relations between body components (soma, gonad and shell weight) and shell height for cultured and wild scallops. Parameters for these equations and the polynomial equation describing relations between somatic weight and age are presented in Table 1. Cultured scallops greater than 8 yr of age were not available, and statistical comparisons between cultured and wild scallops were therefore based on age classes between 2 and $8 \mathrm{yr}$, which were common to both groups. All parameters for polynomial equations describing increasing somatic weight with age were significantly different $\left(\beta_{0}: t=8.30, p<0.001 ; \beta_{1}: t=3.20, p<0.001 ; \beta_{2}: t=\right.$ $3.01, p<0.01)$, and slopes for the shell weight ( $t=$ $2.14, \mathrm{p}<0.05)$ and somatic weight $(\mathrm{t}=5.60, \mathrm{p}<0.001)$ versus shell height logarithmic regressions were also significantly different, lower shell weights and higher somatic weights being observed for cultured scallops of a given shell height. No differences were observed between wild and cultured scallops in prespawned gonad weight versus shell height relations (slope $\mathrm{t}=$ 0.19 ; elevation $t=0.32$ )

\section{Comparison of energy partitioning patterns}

Estimates of reproductive effort for each age class and several somatic weight classes of cultured and wild scallops are presented in Fig. 2a. The low $H_{x}$ value in cultured scallops and the rapid rate with which $P_{g}$ decreased with age suggest that they may not live as long as the wild scallops. In an attempt to standardize the age differential, RE was also related to age expressed as a proportion of expected lifespan (Fig. 2b). Mean lifespan for the cultured scallops was estimated to be $12 \mathrm{Yr}$, based on the length of time to reach the asymptotic height and by extrapolating the declining $\mathrm{P}_{\mathrm{g}}$ values to zero. The lifespan of the wild scallops was estimated to be $20 \mathrm{yr}$.

Reproductive effort in any given age class was higher in the cultured scallops, although after correcting for the effect of a more rapid growth rate reproductive effort was greater for the naturally grown scallops. Greater values for reproductive effort were also observed for the wild scallops when age was expressed as a proportion of the lifespan. Thus, at a point halfway through the lifespan, RE in cultured scallops (54\%) was lower than in scallops grown on the bottom $(77 \%)$.

A final method of comparing energy partitioning was to express cumulative reproductive output as a proportion of total cumulative production for cultured and wild scallops of similar age or somatic weight (Table 3). Proportions of total cumulative production invested in reproduction were similar for cultured and wild scallops of the same age. However, when scallops with similar somatic weights (e.g. Table 2; age 7 yr wild vs age 5 yr cultured) or approximately the same cumulative total production (e.g. age 6 yr wild vs age 
Table 2. Placopecten magellanicus. Mean estimates of shell height $(\mathrm{mm})$, energy equivalents for biomass or somatic weight $(B$; $k J)$, somatic production $\left(\mathrm{P}_{\mathrm{g}} ; \mathrm{kJ} \mathrm{yr}^{-1}\right)$ reproductive output $\left(\mathrm{P}_{\mathrm{r}} ; \mathrm{kJ} \mathrm{yr}^{-1}\right)$, shell production $\left(\mathrm{P}_{\mathrm{s} ;} \mathrm{kJ}_{\mathrm{yr}}{ }^{-1}\right)$, total production $=\mathrm{P}_{\mathrm{g}}+\mathrm{P}_{\mathrm{r}}+$

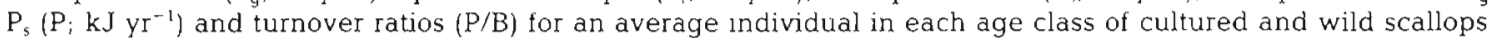

\begin{tabular}{|c|c|c|c|c|c|c|c|}
\hline $\begin{array}{l}\text { Age } \\
\text { (yr) }\end{array}$ & $\begin{array}{c}\text { Shell } \\
\text { height }\end{array}$ & B & $P_{9}$ & $P_{r}$ & $P_{s}$ & $\mathrm{P}$ & $P / B$ \\
\hline \multicolumn{8}{|c|}{ Cultured } \\
\hline 2 & 52.5 & 28.91 & 27.44 & 1.60 & 2.49 & 31.53 & 1.09 \\
\hline 3 & 76.4 & 120.29 & 91.39 & 11.17 & 5.57 & 108.13 & 0.90 \\
\hline 4 & 92.3 & 201.39 & 81.10 & 27.93 & 6.37 & 115.40 & 0.57 \\
\hline 5 & 103.9 & 271.70 & 70.32 & 49.21 & 6.33 & 125.86 & 0.46 \\
\hline 6 & 111.4 & 330.99 & 59.29 & 68.89 & 4.96 & 133.14 & 0.40 \\
\hline 7 & 116.6 & 379.75 & 48.76 & 85.65 & 3.86 & 138.27 & 0.36 \\
\hline 8 & 120.1 & 418.46 & 38.71 & 98.69 & 2.81 & 140.21 & 0.34 \\
\hline \multicolumn{8}{|l|}{ Wild } \\
\hline 2 & 43.0 & 23.52 & 22.05 & 1.56 & 2.03 & 25.64 & 1.09 \\
\hline 3 & 62.3 & 59.54 & 36.02 & 7.71 & 4.37 & 48.10 & 0.81 \\
\hline 4 & 78.8 & 121.52 & 61.99 & 18.35 & 6.46 & 86.80 & 0.71 \\
\hline 5 & 92.9 & 182.03 & 60.52 & 33.25 & 7.70 & 101.47 & 0.56 \\
\hline 6 & 104.8 & 238.38 & 56.35 & 51.07 & 9.05 & 116.47 & 0.49 \\
\hline 7 & 115.0 & 290.08 & 51.70 & 71.55 & 9.20 & 132.45 & 0.46 \\
\hline 8 & 123.7 & 338.10 & 48.02 & 93.10 & 9.16 & 150.28 & 0.44 \\
\hline 9 & 131.1 & 382.20 & 44.10 & 114.64 & 8.82 & 167.56 & 0.44 \\
\hline 10 & 137.4 & 421.64 & 39.45 & 135.92 & 8.27 & 183.64 & 0.44 \\
\hline 11 & 142.8 & 457.66 & 36.00 & 156.14 & 7.70 & 199.84 & 0.44 \\
\hline 12 & 147.4 & 493.68 & 36.02 & 175.02 & 7.01 & 218.05 & 0.44 \\
\hline 13 & 151.3 & 517.94 & 24.26 & 192.58 & 6.29 & 223.13 & 0.43 \\
\hline 14 & 154.6 & 541.70 & 23.76 & 208.27 & 5.55 & 237.58 & 0.44 \\
\hline 15 & 157.5 & 561.78 & 20.00 & 222.64 & 5.06 & 247.70 & 0.44 \\
\hline 16 & 159.9 & 577.71 & 15.93 & 235.14 & 4.33 & 255.40 & 0.44 \\
\hline 17 & 161.9 & 589.96 & 12.25 & 246.05 & 3.71 & 262.01 & 0.44 \\
\hline 18 & 163.7 & 598.53 & 8.57 & 255.89 & 3.40 & 267.86 & 0.45 \\
\hline 19 & 165.2 & 602.94 & 4.41 & 264.40 & 2.89 & 271.70 & 0.45 \\
\hline
\end{tabular}

5 yr cultured) were compared, wild scallops invested more energy in reproduction than did cultivated scallops.

\section{DISCUSSION}

Scallops less than 7 yr old suspended in the water column not only displayed faster rates of shell and somatic tissue growth than did scallops of similar age

Table 3. Placopecten magellanicus. Cumulative total production (CTP; $\mathrm{kJ}$ ) and cumulative reproductive output (CRO; $\mathrm{kJ}$ ) expressed as a proportion of cumulative total production for cultured and wild scallops of similar age

\begin{tabular}{|crrrr|}
\hline \multirow{2}{*}{$\begin{array}{c}\text { Age } \\
(\mathrm{yr})\end{array}$} & \multicolumn{2}{c}{ CTP } & \multicolumn{2}{c|}{ CRO/CTP $\times 100$} \\
& Cultured & Wild & Cultured & Wild \\
\hline 2 & 31.53 & 25.24 & 5.07 & 6.18 \\
3 & 139.65 & 73.34 & 9.14 & 12.64 \\
4 & 255.04 & 160.14 & 15.96 & 17.25 \\
5 & 380.89 & 261.61 & 23.61 & 23.38 \\
6 & 514.03 & 378.08 & 30.89 & 29.63 \\
7 & 652.29 & 510.52 & 37.48 & 35.95 \\
8 & 792.48 & 660.80 & 43.31 & 41.90 \\
\hline
\end{tabular}

grown under natural conditions on the bottom, but also displayed greater reproductive output per annum. Suspended culture has also been shown to improve growth and production in Patinopecten yessoensis (Ventilla
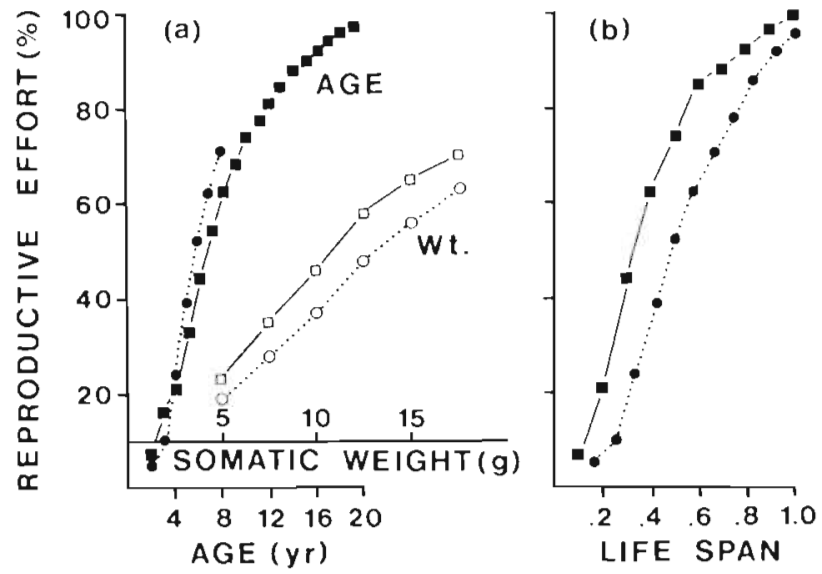

Fig. 2. Placopecten magellanicus. (a) Reproductive effort for each age class of cultured $(\bullet \cdot \cdots \bullet)$ and wild scallops (plus values of reproductive effort after standardization for somatic weight $[$ cultured $=(0 \cdots \cdots)$; wild $=(\square-\square)]$; (b) reproductive effort for each age class expressed as a proportion of lifespan for cultured $(\bullet \cdots \cdot)$ and wild scallops ( $\square$ ) 
1982) and Mytilus edulis (see Lutz 1980 for review; Rodhouse et al. 1984a). Placopecten magellanicus from more favorable shallow-water environments have similar relative growth rates $(k)$ and longevities to conspecifics from deeper water but the former display larger maximum shell heights $\left(\mathrm{H}_{x}\right)$ (MacDonald \& Thompson 1985a). Growing conditions associated with suspended culture of $P$. magellanicus are somewhat artificial but may be considered superior to conditions on the bottom, although the $\mathrm{H}_{\infty}$ estimate for cultured scallops $(128 \mathrm{~mm})$ is much lower than the value obtained for the wild population $(174 \mathrm{~mm})$.

Information from latitudinal studies on bivalves indicate that rapid growth may not be compatible with large size or long life (Seed 1976). The enhanced energy expenditure on growth and reproduction which was observed in cultured scallops during earlier phases of the lifespan may have reduced the potential maximum size for these animals. Scallops occurring naturally in favorable environments may have adapted to their habitat by growing at a moderate rate but achieving a greater maximum size. The rapidity with which cultured scallops reach their maximum size and the rapid decline in their somatic growth while wild scallops the same age are still growing well may be an indication of reduced longevity for cultured scallops in addition to a reduction in maximum size. Results of manipulations such as this are difficult to interpret, but if enhanced reproduction is selected for then a reduction in the lifespan would be expected (Calow 1979). The long-term consequences of a smaller maximum size and reduced longevity on cultivated scallops are of little interest to mariculturists. These cultured scallops will reach marketable size in approximately 3 yr in contrast to the 4 or 5 yr of growth required by scallops living on the bottom.

Better food and temperature conditions measured at another site also resulted in greater growth and gamete production in natural populations of Placopecten magellanicus (MacDonald \& Thompson 1985a, b). The enhanced productivity of cultured scallops in the present study may be a reflection of a more favorable food supply and/or temperature regime in the water column than on the bottom. Rodhouse et al. (1984a) came to similar conclusions in a study of the mussel Mytilus edulis, and drew attention to differences in food quality as well as food quantity. Thus, although the concentrations of chlorophyll a did not differ between suspended culture locations and those where mussels grew on the bottom, the food available to cultured mussels consisted mainly of phytoplankton cells, whereas the food supply for wild mussels was composed of allochthonous detrital material plus phytoplankton. Each food source conferred advantages and disadvantages depending on the season.
Scallops held in the water column are less likely to experience such high concentrations of resuspended sediment than are those individuals living on the bottom, where fine sediments are often found and may frequently be resuspended. In general, it is difficult to assess the possible influence of suspended sediments on bivalve feeding and energetics. For example, negative influences of high concentrations of inorganic particulate material include increased pseudofaecal production and lower ingestion rates for Mytilus edulis (Widdows et al. 1979), Chlamys islandica (Vahl 1980) and Spisula solidissima (Robinson et al. 1984), which may be partially responsible for lower productivity in wild Placopecten magellanicus seen in this study. A near-bottom benthic turbidity zone characterized by higher concentrations of suspended material than are found in the overlying water column has been described for an extensive area of Long Island Sound, and zones may be widespread features of estuaries and embayments (Rhoads et al. 1984). Alternatively, these authors suggested that suspended material in the benthic turbidity zone may be very nutritious to suspension feeders, and they presented evidence for acceptable bivalve growth rates, identifying it as a potential area for bottom rack mariculture. The presence of suspended bottom material in bivalve diets has been shown to enhance growth in experimental studies on Spisula subtruncata and $M$. edulis (Kiørboe et al. 1981, Møhlenberg \& Kiørboe 1981). The feeding responses of bivalves experiencing high and variable seston levels and any mechanisms that facilitate positive energy balance, such as the preferential sorting and ingestion of organic over inorganic particles, are of fundamental ecological interest and worthy of future research consideration.

After standardization for growth rate and lifespan, the data showed that cultivated scallops allocated relatively more of their available energy to somatic growth resulting in lower estimates of reproductive effort (RE) than those observed for a comparable wild population. Rodhouse et al. (1984b) have also presented evidence for increased expenditures on growth and consequently lower RE in cultured Mytilus edulis.

An animal's response to variable environmental factors may depend on the nature of experimental regimes and whether they represent abrupt unpredictable changes or natural fluctuations in which there may have been time for adaptation to occur (Thompson 1984). For example, within the natural range of environmental conditions experienced by Mytilus edulis (Bayne et al. 1983) and Placopecten magellanicus (MacDonald et al. unpubl.), RE was higher for bivalves collected from more favorable environments, which is consistent with current life history theory (Goodman 1979). However, stressful conditions induced by experimental manipu- 
lations have been shown to elicit the opposite response, an increase in RE primarily due to relatively less emphasis on growth, or even to somatic tissue degrowth (Calow \& Woollhead 1977, Hirshfield 1980, Thompson 1983) which also may be accompanied by reduced reproductive output. The artificial but long-term conditions associated with suspended culture appear to be superior to those encountered in the natural bottom environment, resulting in lower $R E$ values because of enhanced investment in somatic tissue by young scallops. However, it is impossible to evaluate the contribution of somatic growth to reproduction in species such as this where reproductive output is well correlated with size (Tuomi et al. 1983). A switch in resource allocation from reproduction to growth would be advantageous to mariculturists by increasing marketable meat weights. This has been achieved in Argopecten irradians by genetic manipulation (Tabarini 1984).

Understanding the circumstances under which energy partitioning patterns are altered by variable environmental factors will assist in assessing potential consequences of such changes to individuals and populations. Despite similarities in mortality patterns and egg characteristics, fitness is greatly reduced in populations of Placopecten magellanicus from less favorable environments, as evidenced by lower fecundities and reduced RE (MacDonald et al. unpubl.). Apparent consequences of reduced maximum size and longevity for cultured scallops include a reduction in reproductive output or reproductive value over the lifespan from $2800 \mathrm{~kJ}\left(\sim 1.0 \times 10^{9}\right.$ eggs $)$ to $800 \mathrm{~kJ}\left(\sim 0.3 \times 10^{9}\right.$ eggs $)$, which presumably represents a considerable reduction in fitness. However, interpretation is complicated by potentially different rates of survival for offspring and it is difficult to assess the positive influence on fitness of cultivated scallops producing more gametes in early years and the compound effect of these additional offspring reproducing.

In conclusion, 3 basic patterns of variation in energy partitioning patterns in response to fluctuating environmental conditions have been reported in the literature for invertebrates. First, within the range of environmental conditions normally experienced by the animal, RE increases when circumstances improve; secondly, extreme stress results in elevated RE estimates because animals restrict or reduce their growth in order to maintain reproduction; and, finally, improved conditions associated with suspended culture reduce RE due to a preferential allocation of available energy to growth.

Acknowledgements. I thank G. Chaisson, R. Guest, R. O'Donnell, J. Woolridge, J. Ennis, and A. Barnes for their diving assistance in the field, and J. Senciall for help in the laboratory. Cultured scallops from Spencers Cove were provided by K. Naidu and F. Cahill at the Department of Fisheries and Oceans in St. John's. R. Thompson provided valuable criticism of the manuscript. Financial support was provided by a Marine Sciences Research Laboratory scholarship, a Faculty of Graduate Studies, Memorial University of Newfoundland fellowship and funds from a Natural Sciences and Engineering Research Council operating grant to R. Thompson. Marine Sciences Research Laboratory Contribution No. 660.

\section{LITERATURE CITED}

Bayne, B. L., Newell, R. C. (1983). Physiological energetics of marine molluscs. In: Saleuddin, A. S. M., Wilbur, K. M. (ed.) The Mollusca, Vol. 4 (1). Academic Press, New York, p. $407-515$

Bayne, B. L., Salkeld, P. N., Worrall, C. M. (1983). Reproductive effort and value in different populations of the marine mussel Mytilus edulis L. Oecologia (Berl.) 59: 18-26

Broom, M. J. (1983). Mortality and production in natural, artificially seeded and experimental populations of Anadara granosa (Bivalvia: Arcidae). Oecologia (Berl.) 58: 389-397

Browne, R. A., Russell-Hunter, W. D. (1978). Reproductive effort in molluscs. Oecologia (Berl.) 37: 23-27

Caddy, J. F. (1972). Progressive loss of byssus attachment with size in the sea scallop, Placopecten magellanicus (Gmelin). J. exp. mar. Biol. Ecol. 9: 179-190

Calow, P. (1979). The cost of reproduction: A physiological approach. Biol. Rev. 54: 23-40

Calow, P., Woollhead, A. S. (1977). The relationship between ration, reproductive effort and age-specific mortality in the evolution of life history strategies: Some observations on freshwater triclads. J. Anim. Ecol. 46: 765-781

Goodman, D. (1979). Regulating reproductive effort in a changing environment. Arm. Nat. 113: 735-748

Griffiths, R. J. (1981). Production and energy flow in relation to age and shore level in the bivalve Choromytilus meridionalis (Kr.). Estuar. coast. Shelf Sci. 13: 477-493

Hawkins, A. J. S., Bayne, B. L. (1985). Seasonal variation in the relative utilization of carbon and nitrogen by the mussel Mytilus edulis: budgets, conversion efficiencies and maintenance requirements. Mar. Ecol. Prog. Ser. 25: 181-188

Hirshfield, M. F. (1980). An experimental analysis of reproductive effort and cost in the Japanese Medaka, Oryzias latipes. Ecology 61: 282-292

Hughes, R. N. (1970). An energy budget for a tidal-flat population of the bivalve Scrobicularia plana (da Costa). J. Anim. Ecol. 39: 357-379

Hughes, R. N., Roberts, D. J. (1980). Reproductive effort of winkles (Littorina spp.) with contrasted methods of reproduction. Oecologia (Berl.) 47: 130-136

Kiørboe, T., Møhlenberg, F., Nøhr, O. (1981). Effect of suspended bottom material on growth and energetics in Mytilus edulis. Mar. Biol. 61: 283-288

Lutz, R. A. (ed.) (1980). Mussel culture and harvest: A North American perspective. Elsevier, Amsterdam

MacDonald, B. A., Thompson, R. J. (1985a). Influence of temperature and food availability on the ecological energetics of the giant scallop Placopecten magellanicus. I. Growth rates of shell and somatic tissue. Mar. Ecol. Prog. Ser. 25: 279-294

MacDonald, B. A., Thompson, R. J. (1985b). Influence of temperature and food availability on the ecological 
energetics of the giant scallop Placopecten magellanicus. II. Reproductive output and total production. Mar Ecol. Prog. Ser. 25: 295-303

MacDonald, B. A., Thompson, R. J. (1986). Influence of temperature and food availability on the ecological energetics of the giant scallop Placopecten magellanicus. III. Physiological ecology, the gametogenic cycle and scope for growth. Mar. Biol. (in press)

Merrill, A. S., Posgay, J. A., Nichy, F. E. (1966). Annual marks on shell and ligament of sea scallop Placopecten magellanicus. Fish. Bull. U.S. 65: 299-311

Møhlenberg, F., Kiørboe, T (1981). Growth and energetics in Spisula subtruncata (da Costa) and the effect of suspended bottom material. Ophelia 20: 79-90

Neter, J., Wasserman, W., Kutner, M. H. (1983). Applied linear regression models. Irwin Publishers, Homeland, Illinois, p. 547

Rhoads, D. C., Boyer, L. F., Welsh, B. L., Hampson, G. R. (1984). Seasonal dynamics of detritus in the benthic turbidity zone (btz). Implications for bottom-rack molluscan mariculture. Bull. mar. Sci. 35: 536-549

Robinson, W. E., Wehling, W. E, Morse, M. P. (1984). The effect of suspended clay on feeding and digestive efficiency of the surf clam, Spisula solidissima (Dillwyn). J. exp. mar Biol. Ecol. 74: 1-12

Rodhouse, P. G., Roden, C. M., Burnell, G. M., Hensey, M. P., McMahon, T., Ottway, B., Ryan, T H. (1984a). Food resource, gametogenesis and growth of Mytilus edulis on the shore and in suspended culture: Killary Harbour, Ireland. J. mar. biol. Ass. U.K. 64: 513-529

Rodhouse, P. G., Roden, C. M., Hensey, M. P., Ryan, T. H. (1984b). Resource allocation in Mytilus edulis on the shore and in suspended culture. Mar. Biol. 84: 27-34

Seed, R. (1976). Ecology. In: Bayne, B. L. (ed.) Marine mussels - their ecology and physiology. Cambridge University Press, Cambridge, p. 13-65

Seed, R. (1980). Shell growth and form in the Bivalvia. In: Rhoads, D. C., Lutz, R. A. (ed.) Skeletal growth of aquatic organisms. Plenum Press, New York, p. 23-68

Shafee, M. S., Conan, G. (1984). Energetic parameters of a population of Chlamys varia (Bivalvia: Pectunidae). Mar. Ecol Prog. Ser. 18: 253-262

Snedecor, G. W., Cochran, W. G. (1972). Statistical methods The Iowa State University Press, Iowa, p. 593

Stevenson, J. A., Dickie, L. M. (1954). Annual growth rings and rate of growth of the giant scallop, Placopecten magellanicus (Gmelin) in the Digby area of the Bay of Fundy. J. Fish. Res. Bd Can. 11: 660-671

Tabarini, C. L. (1984). Induced triploidy in the bay scallop Argopecten irradians, and its effect on growth and gametogenesis. Aquaculture 42: 151-160

Thompson, R. J. (1977). Blood chemistry, biochemical composition and the annual reproductive cycle in the giant scallop, Placopecten magellanicus, from southeast Newfoundland. J. Fish. Res. Bd Can. 34: 2104-2116

Thompson, R. J. (1983). The relationship between food ration and reproductive effort in the green sea urchin Strongylocentrotus droebachiensis. Oecologia (Berl.) 56: 50-57

Thompson, R. J. (1984). Production, reproductive effort, reproductive value and reproductive cost in a population of the blue mussel Mytilus edulis from a subarctic environment. Mar. Ecol. Prog. Ser. 16: 249-257

Tuomi, J., Hakala, T., Haukioja, E. (1983). Alternative concepts of reproductive effort, costs of reproduction and selection in life history evolution. Am. Zool. 23: 25-34

Vahl, O. (1980). Seasonal variations in seston and the growth rate of the Iceland scallop, Chlamys islandica (O. F. Müller) from Balsfjord, $70^{\circ} \mathrm{N}$. J. exp. mar. Biol. Ecol. 48: 195-204

Vahl, O. (1981). Energy transformations by the Iceland scallop, Chlamys islandica (O. F. Müller), from $70^{\circ} \mathrm{N}$ I. The age-specific energy budget and net growth efficiency. J. exp. mar. Biol. Ecol. 53: 281-296

Ventilla, R. F. (1982). The scallop industry in Japan. Adv. mar. Biol. 20: 309-382

Widdows, J., Fieth, P., Worrall, C. M. (1979). Relationships between seston, available food and feeding activity in the common mussel Mytilus edulis. Mar. Biol. 50: 195-207

Zar, J. H. (1984). Biostatistical analysis. (2nd edn). Prentice Hall, New Jersey, p. 718

This article was submitted to the editor; it was accepted for printing on September 22, 1986 